\title{
Change, Continuity, and the Evolution of the Law
}

\author{
Forrest Maltzman George Washington University \\ Charles R. Shipan University of Michigan
}

\begin{abstract}
Congress regularly passes significant laws. Some of these laws continue in their initial form, with the original bargain struck by the enacting coalition untouched by any future laws; others are changed-strengthened or weakened-soon after passage. What accounts for this variation in the stability of laws, in the longevity of the original legislative agreement? We contend that political conditions at the time of enactment - in particular, the existence of divided government and the level of ideological disagreement between the House and Senate-influence the likelihood that a law will be amended. We demonstrate that laws originally crafted by diverse political coalitions are less durable than those crafted by strong, unified coalitions, which are in a position to entrench their preferred policies and protect them from future change. Furthermore, we show that the probability of a law being amended is affected by future political conditions, the actions of the judiciary, and factors specific to the law.
\end{abstract}

$\mathrm{T}$ he importance and influence of public policies depend upon their durability. Whereas some laws guide policies for decades, others have only a transitory influence on policy. Soon after enactment, they are swiftly amended and superseded by new law. Despite such variance, our understanding of the stability of public laws and the conditions that foster such variation is limited. What forces help to shape whether initial agreements among legislators endure or unravel? This question has received scant attention from legislative scholars, whose studies of policymaking typically focus on the dynamics of enacting laws rather than on what happens after enactment.

We explore the political conditions that influence whether a law becomes amended in future years. In contrast to most legislative studies, which examine how political conditions affect the probability of enacting major policy change, we explore the conditions that increase the likelihood that major laws will be reviewed and changed in the future. And in contrast to public policy scholars, who have produced theoretically informed studies of the ways in which post-enactment politics (e.g., policy feedback loops and changes among organized interests) sustain new laws after enactment, we step back to focus on the ways in which political conditions at the time of enactment may affect the life of federal laws. Our central theme is that variation in the political conditions at the time of enactment has long-lasting consequences for the duration of the law. ${ }^{1}$ More specifically, we argue that conditions at the time of enactment determine whether a law is crafted in such a way that it accomplishes its sponsors' objectives and is immunized against subsequent revision; whether a law fails to secure its advocates' objectives and needs to be strengthened; or whether a law is left vulnerable to subsequent legislative attacks.

Substantive changes to the original agreement are important for two main reasons. First, the longer a law lasts before it is amended, the greater its potential to shape the nation's economic, social, and political welfare. Second, much of the value of laws - to interest groups, legislators,

Forrest Maltzman is professor of political science, George Washington University, 440 Monroe Hall, Washington, DC, 20052 (forrest@gwu.edu). Charles R. Shipan is the J. Ira and Nicki Harris Professor of Social Science, Department of Political Science, University of Michigan, 505 S. State Street, Ann Arbor, MI 48109-1045 (cshipan@umich.edu).

The authors gratefully acknowledge the advice of Scott Adler, Sarah Binder, Fred Boehmke, Barry Burden, Will Howell, John Huber, Eric Lawrence, Gerald Loewenberg, Bill Lowry, David Mayhew, Dan Morey, Alison Post, Eric Patashnik, Paul Pierson, Elizabeth Rybicki, Paul Wahlbeck, Matt Whittaker, and the anonymous reviewers; the willingness of Sarah Binder, David Epstein, Sharyn O'Halloran, Jim Stimson, and David Mayhew to share their data; and Karen Ramsey's and Ken Moffett's superb research assistance. Shipan gratefully acknowledges the financial assistance of a University of Iowa Faculty Scholar Award and Maltzman the financial assistance of the National Science Foundation (SES-0351469).

${ }^{1}$ Throughout this article we use terms such as durability, stability, and longevity interchangeably. These terms all indicate our primary focus on the length of time between when a law is initially passed (i.e., the original agreement) and when that law is amended-either strengthened or weakened-by a future Congress.

American Journal of Political Science, Vol. 52, No. 2, April 2008, Pp. 252-267 
and so on-comes from the original agreement. When this agreement is revised, regardless of whether the revision weakens or strengthens the law, such changes affect the value of that law to the original participants. Indeed, subsequent amendments provide the opponents of a bill another opportunity to enact provisions that may undermine, if not cripple, the original intention of the law. Likewise, subsequent amendments that strengthen or expand a bill suggest that the original law failed to accomplish the policy objectives of at least some of its advocates.

For these reasons, members of the original coalition—members of Congress and the president-will want to write laws that both accomplish their policy objectives and bind future lawmaking coalitions. We will contend, however, that they are better able to do so under certain conditions. Because legislators are frequently unable to constrain future policymaking coalitions (Berry, Burden, and Howell 2006; Moe 1989; Patashnik 2000, 2003), federal laws vary in terms of their stability. Although some laws, such as the Civil Service Reform Act of 1978 , become institutionalized in such a way that no meaningful changes are made and their effects are felt for decades, other laws, such as the 1980 Toxic Wastes Superfund Act, are dramatically amended soon after enactment. Such amendments can enhance or diminish the effectiveness of the original law. Regardless of the nature of such amendments, the amendments themselves are evidence that members of the initial coalition were unable to craft a law that secured the policy outcomes they desired into the future.

To test our model of legislative stability, we examine the fate of major laws enacted between 1954 and 2002. First, we show that not all of these laws are equally enduring. Second, we identify the factors that influence whether a major law will be amended and develop an empirical model that accounts for why and when some prominent laws are amended by other major pieces of legislation. We show that initial conditions of enactment-along with later conditions, features specific to the law itself, and the actions of the judiciary-have systematic and predictable consequences for the sustainability of the original versions of public laws.

\section{The Life and Value of the Law}

Scholars have long recognized that new public laws are not immutable (e.g., Pierson 2004). Policies and organizations that many once viewed as entrenched (e.g., the welfare state, airline regulation, and the Interstate Commerce Commission) have been dramatically recast or even dismantled (Berry, Burden, and Howell 2006; Derthick and
Quirk 1985; Lewis 2003, 2004; Patashnik 2003; Pierson $1994,2004)$. As Pierson has noted, it is commonly believed that "policies, unlike formal institutions, are relatively easy to change (or 'plastic'), they are essentially epiphenomenal" (2003, 2-3). Policy scholars who focus on the outputs of the legislative process have been attentive to the stability of public policy, since the life span of a law is essential to assessing its initial value (Kelly 1993; Patashnik 2000, 2003, 2008). For example, Landes and Posner (1975) argue that the payoffs that legislators extract from organized interests for enacting policies that benefit those groups are limited by the recognition that the winning coalition cannot make credible long-term commitments to sustain the law.

The political value of stable law has encouraged some to focus on the forces that promote legislative permanence. Some argue that constitutional features of the American political system help promote legislative continuity. Landes and Posner (1975), for example, claim that an independent judiciary helps to ensure policy stability, thereby increasing the value of legislation to groups and members of Congress (see also McCubbins, Noll, and Weingast 1989; Moe 1989). Supermajority requirements (Binder and Smith 1997; Brady and Volden 1998; Krehbiel 1998), the presence of multiple veto points (de Figueiredo 2002; Ferejohn and Shipan 1990; Tsebelis 2002), and bicameralism (Binder 2003) are also credited with making legislative enactments difficult to achieve, and thus potentially more stable over time.

Public policy scholars also have explored the ways in which well-designed policies can be preserved. Institutional provisions embedded in specific legislative acts may ensure programmatic stability, as seen in Patashnik's (2000) demonstration that winning politicians use federal trust funds as a vehicle for reducing uncertainty about future commitments to the programs and for binding their successors. The durability of laws that create agencies can be enhanced by removing the agency from OMB budget review, giving appointees a fixed term, and imposing a party-balancing requirement for nominees (Lewis 2004). Policies also can be extended by mobilizing groups and shaping interests so that the public and dominant interests seek to preserve the status quo (e.g., Patashnik 2003, 203). For example, Hacker $(2002,2005)$ and Hacker and Pierson (2002) argue that the emergence of the welfare state altered ideas about the capacity of the state and about preferred policy choices, thus constraining future generations.

More generally, winning legislators also have a strong incentive to consolidate their victories. A winning legislator's central goals are both to lock in policy gains and to secure programs that automatically will be revised 
in ways consistent with his or her preferences as conditions change. Thus, legislators concerned about greenhouse gases routinely lobby for emission standards that are strengthened automatically as technology improves. Likewise, advocates of Social Security support indexing the payments to an inflation index. This incentive to lock in policy successes is especially strong in a system (such as the United States) where no party has clear dominance (de Figueiredo 2002). At the same time, losing legislators have the opposite incentive: they want enacted policies subsequently to fail. This failure can occur through either the complete revocation of a law, significant amendment of its basic parts, or even the enactment of policies that alter or fail to satisfy the long-term objectives of the initial law's advocates. ${ }^{2}$

In the American political context, tools available for losers seeking to either cripple or expand existing laws are plentiful. One strategy is to work to craft the law in such a way that invites review by the judiciary-for instance, by pushing for the inclusion of vague, inconsistent, or even unconstitutional provisions. Accompanying unconstitutional provisions with an inseverability clause can force the Court to declare unconstitutional a new law favored by the president and a majority of Congress. ${ }^{3}$ Opponents of new policies can also advocate inclusion of sunset provisions, temporally limited reauthorizations, or other provisions that are likely to encourage the public and organized interests to lobby against successful implementation.

Legislative scholars have been attuned to these dynamics of the legislative process, paying keen attention to the ways in which political and institutional forces shape the likelihood of major policy change (e.g., Adler and Lapinski 2006; Brady and Volden 1998; Krehbiel 1998). ${ }^{4}$ These studies have advanced our understanding of the policymaking process by delineating the conditions that make the enactment of major laws more likely. Central to many of these studies is the debate over the influence of interbranch and intrabranch policy differences on the likelihood of enacting new law (e.g., Binder 2003; Coleman 1999; Howell et al. 2000; Kelly 1993; Mayhew 2005). Still, such studies essentially end at the stage of enactment. ${ }^{5}$ Given the substantial variation in the longevity of public

${ }^{2}$ The failure of the 1974 Federal Elections Campaign Act to index contribution limits undermined the act (Abraham 2000). This led, in part, to the 2002 Bipartisan Campaign Reform Act.

${ }^{3}$ Opponents of the 2002 Bipartisan Campaign Reform Act pursued this strategy (Saletan 2001).

${ }^{4}$ Recent studies are also paying renewed attention to the policy content of legislation. See in particular Adler et al. (2005), Covington and Bargen (2004), and Katznelson and Lapinski (2006).

${ }^{5}$ Baumgartner and Jones $(1993,2005 \mathrm{~b})$ develop and test arguments about the effects of institutional factors on, among other things, the laws, we need to ask whether the politics of enactment have discernible consequences for the durability of new laws.

\section{Determinants of Stability}

What factors can account for the variation in the stability of a newly passed law? First and foremost, the political environment at the time of passage influences the length of time until a law is amended. Second, subsequent political conditions also determine whether a law is amended. Third, characteristics of the law itself will affect its longevity.

\section{Enactment Political Conditions}

Political competition over the shape of a new public law has predictable consequences for the likelihood of crafting law that is less susceptible to subsequent amendment. Because the character of such competition is strongly influenced by the political conditions that prevail during the period of enactment, we explore the ways in which these initial conditions affect a law's stability, shaping both the capacity and incentives of legislators to seek durable outcomes. One of the most important factors at the time of passage is the existence of divided government.

As noted in the previous section, legislative scholars have devoted considerable time and energy to examining the effects of divided government on the passage of legislation (e.g., Binder 2003; Mayhew 2005). Most of the arguments and analyses, however, have focused solely on whether divided government increases or decreases the likelihood of initial passage. And while there exists disagreement about the effect of divided control on the passage of laws, scholars have little sense of how divided government-or more generally, ideological disagreements among the House, the Senate, and the presidentmight affect the future of laws that do pass.

At first blush, one might expect that if it is more difficult for politicians to pass laws under divided government (e.g., because it is harder for them to reach agreement on the principles that should be embodied in a law), then we might expect that when a law does pass under divided government, it is more likely to live a long life, undisturbed by future Congresses and unamended by future laws. According to this view, laws that pass in the presence of disagreements between the House and Senate, or in the presence of disagreement between the branches,

amount of attention paid to various issues and why this attention changes over time. 
require compromises that will bring both Republicans and Democrats on board and that then should increase the likelihood that the original bargain will last well into the future. This conventional view is captured by Niskanen's assertion that "the probability that a major reform will last is usually higher with a divided government, because the necessity of bipartisan support is more likely to protect the reform against a subsequent change in the majority party" $(2003,2)$.

In contrast to this view, we find more persuasive, albeit perhaps also more counterintuitive, the argument that laws will be more stable, and that the original agreement will last longer, when control of government is unified at the time of enactment. In other words, we contend that laws passed under divided government are more, not less, likely to be amended than laws passed under unified government. Three lines of argument support this contention.

First, laws passed under unified control will be more coherent and internally consistent, due to the shared policy interests across institutions (e.g., Sundquist 1988). Laws passed under divided government, on the other hand, require compromises that can take the form of vague or internally inconsistent provisions or that can result in a broader (and less coherent) range of provisions. Such compromises work to bring enough legislators and the president on board, allowing the bill to pass, but these compromises completely satisfy few of these actors. ${ }^{6}$ Consequently, laws passed under unified control provide a narrower target for opponents than laws passed under divided control. In other words, "coalitions under divided control, being composed of elements not 'naturally' united on policy goals, might be less apt to write either clear ends or efficient means into their statutes" (Mayhew 2005, 180).

Instances of laws that fit this description are easy to find. In signing the 1996 Welfare Reform law, President Clinton asserted that he signed the bill despite its "serious flaws" because it was the "best chance we will have in a long, long time" (Harris and Yang 1996). Another example is the Energy Policy and Conservation Act of 1975. This act, "an awkwardly stitched-together compromise" (Mayhew 2005, 180) that "satisfied no one" (Vietor 1984, 249), had a number of provisions that virtually ensured Congress's continued involvement in U.S. energy policy. Perhaps the most controversial provision was the creation of a unicameral legislative veto over executive branch de-

${ }^{6}$ Moe similarly observes, in the context of statutes that design bureaucracies, that the need for political compromise "ushers the fox into the chicken coop" and results in winners and losers in the legislative process placing differing and conflicting provisions into laws $(1989,276)$. cisions regarding the price for domestically produced oil. After a great deal of hesitation, President Ford signed the bill. The act was significantly amended only a few years later, in 1980.

Second, laws passed under unified government are more likely to contain self-executing provisions that enable the law to evolve to current circumstances. Examples of self-executing provisions include an automatic cost of living adjustment (Weaver 1988) or a funding mechanism, such as the domestic-segment tax on air transportation, which automatically adjusts to changing needs (e.g., increased air traffic). Likewise, laws passed under divided government may lack the sort of self-executing provisions that immunize laws from necessary revisions or may contain provisions that specifically open the laws up to future changes. That is, legislative fragmentation induced by divided government creates an incentive to craft measures in such a way that encourages future legislators to revisit the law-for instance, through the inclusion of sunset provisions, such as those found in the 1996 Welfare Reform law, or short authorization periods. ${ }^{7}$ Under unified government, on the other hand, we would expect legislators to seek to protect their policy choices from political intrusion, for instance by creating bureaucratic institutions that insulate the policy from political influence (Moe 1989).

Third, recent theories and findings from studies of legislative delegation also support the argument that the original agreement will last longer for laws passed under divided control than for laws passed under unified control. In particular, legislators are more likely to attempt to limit executive branch discretion during periods of divided government by adopting laws that spell out in detail which policies should be implemented (Huber and Shipan 2002; Huber, Shipan, and Pfahler 2001). ${ }^{8} \mathrm{Al}-$ though these kinds of laws provide certain benefits to legislatures, such as potentially preventing bureaucrats from using their informational advantages to implement policies that legislators do not like, they also come with some costs. The most relevant cost from the standpoint of our analysis is that the sorts of precise, detailed laws that divided government produces are more likely to instruct

\footnotetext{
${ }^{7}$ Sunset provisions can be viewed as either a causal factor that affects legislative durability or as a by-product of legislative fragmentation. Our own view is closer to the latter - that is, these and other similar sorts of provisions are likely to be caused by the same factors that also determine legislative durability. Still, because sunset provisions certainly can represent attempts by legislators to increase the probability of significant revision, in our empirical analysis we will account for the effects of such provisions.

${ }^{8}$ Congress is more likely to pass laws that limit the executive branch's discretion under divided government than under unified government (Epstein and O’Halloran 1999).
} 
bureaucrats to take specific actions and less likely to provide bureaucrats with the flexibility they would need in order to respond to exogenous shocks. When conditions do change in the future, the specific provisions in the original law may no longer be adequate and may even be inappropriate. Thus, a detailed law is more likely to need a legislative fix than is a law that provides bureaucrats with the flexibility to adapt to changing circumstances; and divided government is more likely to produce detailed laws.

Taken together, these arguments suggest that unified government will produce longer-lasting laws. Thus, our first hypothesis captures the idea that original legislative agreements will last longer when Congress and the president are controlled by one party; and conversely, that laws passed when parties share control of government are more likely to be amended.

Divided Government at Enactment: Laws enacted during periods of divided government are more likely to be amended than those enacted under unified control.

Recent work on the influence of bicameralism on lawmaking suggests that the alignment of preferences in bicameral legislatures may also affect policy outcomes. Several scholars, for example, have shown that bicameralism makes policy change more difficult (e.g., Hammond and Miller 1987; Tsebelis and Money 1997). Correspondingly, Tsebelis (2002) and Binder (2003) have argued that the chances of overturning the policy status quo are strongly shaped by the policy differences between chambers of bicameral institutions. In that context, successful policy adoption depends on finding an overlap in preferences between pivotal players in both chambers. By broadening the scope of policy views that must be incorporated into final policy choices, the potential for writing durable law is compromised. This leads us to the following hypothesis:

Bicameral Differences at Enactment: The greater the policy disagreement between the House and Senate, the greater the probability of amendment.

\section{Subsequent Political Conditions}

Our main focus so far has been on the effect of political and institutional factors at the time of enactment. Of course, the probability of a law being amended will depend upon more than just the political conditions at the time of enactment. Conditions that exist after enactment also are likely to affect the chances that Congress will succeed in passing another major law that revises the initial law. Although, as we noted earlier, findings on the relationship between divided government and the passage of major laws have been mixed, several recent studies have demonstrated that many types of major laws are more likely to be passed under unified government than under divided government (e.g., Coleman 1999; Howell et al., 2000; Kelly 1993; but see Mayhew 2005). Hence, successful amendments, being laws themselves, should be more likely to occur under unified control.

Similarly, the degree of bicameral differences will shape not only the likelihood of initial enactment of a stable law, but also subsequent efforts to revise earlier decisions. Two chambers that are ideologically distant from each other will have more difficulty reaching a consensus to pass a new law than will two chambers that share similar preferences (e.g., Binder 2003) and consequently will be less likely to pass laws that amend existing laws. Overall, then, we would expect that subsequent political conditions, in addition to the conditions at the time of enactment, will affect the stability of public laws. The following two hypotheses capture this idea:

Subsequent Divided Government: During periods of divided government, existing major laws are less likely to be amended.

Subsequent Bicameral Differences: The greater the policy differences between the two chambers, the less likely it is that existing major laws will be amended.

The probability of congressional action also is likely to depend upon the prevailing public mood (Coleman 1999; Mayhew 2005; Stimson 1991). As Mayhew has described, these moods act as "stimulators of legislation" $(2005,163)$. Similarly, Kingdon has argued that ". . . changes in mood or climate have important impacts on policy agendas and policy outcomes" and that this national mood can either push items for change onto the agenda or serve as a constraint $(1984,153)$. Based on this logic, we predict the following relationship:

Policy Mood: During periods when the public favors government action, existing major laws are more likely to be amended.

The probability that public laws will be amended may depend in part upon the treatment of new laws by the judicial branches. As many scholars have observed, interactions between Congress and the courts often guide the development of public law. Congress often takes the courts 
into account when writing laws, either by anticipating judicial actions (e.g., Lovell 2003; Shipan 1997, 2000; Smith 2005, 2006) or, perhaps less commonly, by responding directly to judicial decisions (e.g., Barnes 2004; Eskridge 1991). But another way the Supreme Court can influence Congress is by signaling the emergence of a policy problem. For example, the meaning of a public law can be so ambiguous that the Court's interpretation of the law encourages congressional revision (Hausegger and Baum 1999). Given the interaction of the Court and Congress, we would expect to find a systematic influence of Court activity on Congress's treatment of public laws:

Subsequent Court Intervention: The greater the attention of the Supreme Court to the policy area of a public law, the more likely the law will be amended.

\section{Law-specific Characteristics}

Although legislative scholars tend to downplay the ways that the substance of policies can shape political dynamics, as Katznelson, Lapinski, and Razaghian (2001) have pointed out, public policy scholars have frequently noted that politics is shaped in part by the nature of the policy (e.g., Lowi 1964). Thus, we control for the possibility that the likelihood of revisiting a law is affected by characteristics specific to the original legislation. Here, we focus on two features of each law.

We begin with the law's complexity. Some laws, such as the Financial Institutions Reform, Recovery, and Enforcement Act of 1989, clearly are complex in nature, while others, such as the Public Health Cigarette Smoking Act of 1969, which banned cigarette advertising on radio and television, are relatively straightforward. Generally, more complex bills have more provisions, they touch on more issues and policy areas (which present more targets for future amendment), and their effects are more uncertain. As such, both opponents and proponents of the initial law are more likely to pursue future amendments. Hence, we propose the following relationship between complexity and durability:

Complexity: Major laws that are more complex are more likely to be amended. ${ }^{9}$

\footnotetext{
${ }^{9}$ Complexity could, of course, be considered another aspect of the conditions at enactment, as the complexity of a law is determined at the time of enactment. Unlike divided government and interchamber agreement, however, complexity is not a specific feature of the political landscape during enactment, but varies by law, which is why we consider it here.
}

In addition to the effects of a law's complexity, a law's contentiousness may affect the likelihood that it will be amended. Simply put, laws that encounter greater opposition when they originally pass are more likely to be amended than laws that command broad support. Divisive laws are more prone to amendment for several reasons. First, because support is shallow, modest turnover in Congress can cause this support to erode. Second, when a law passes with a small majority, it is more likely that narrowly tailored provisions are incorporated into the initial law as a vehicle for appeasing a necessary supporter. Such provisions may have little to do with the broad goals of a bill and thus may be more likely to be vulnerable to a future coalition that no longer needs the support of the legislator who was initially enticed to join the majority. Finally, the absence of overwhelming support at the time of adoption may have prevented supporters of the original law from securing provisions that would enhance stability.

Overall, divisive laws are less likely to be protected against future laws. As Arnold has explained, "Oversized majorities protect programs in the long run against defections, the retirement or defeat of habitual supporters, or changes in the mood of Congress" (1990, 118). Similarly, Landes and Posner argued that "to guarantee legislative stability," the initial vote enacting the legislation needs to be "one-sided" (1975, 878). The 1958 Price-Anderson Nuclear Industry Indemnity Act, for instance, was originally adopted by voice vote in the House and Senate. Since its enactment, it has never been amended. In contrast, legislation that attracts considerable dissent is more likely to be revisited, given the limited ability of the enacting coalition to entrench the chosen policy decision. For example, the 1965 Housing and Urban Development Act, which was adopted with the support of only 217 members of the House and 57 senators, was significantly amended only a few years later, in 1968. Thus, we expect that laws that are more contested and that narrowly pass will be more susceptible to future revisions:

Divisiveness: Major laws adopted by slim majorities are more likely to be amended.

\section{Data}

To test our conjectures about the conditions that increase the stability of laws, we need to identify a set of laws and then determine whether these laws have been significantly revised. We begin by using the list of major laws identified by Mayhew (2005), focusing on the laws enacted between 


\section{FIGURE 1 Number of Years Until Amendment for Major Legislation}

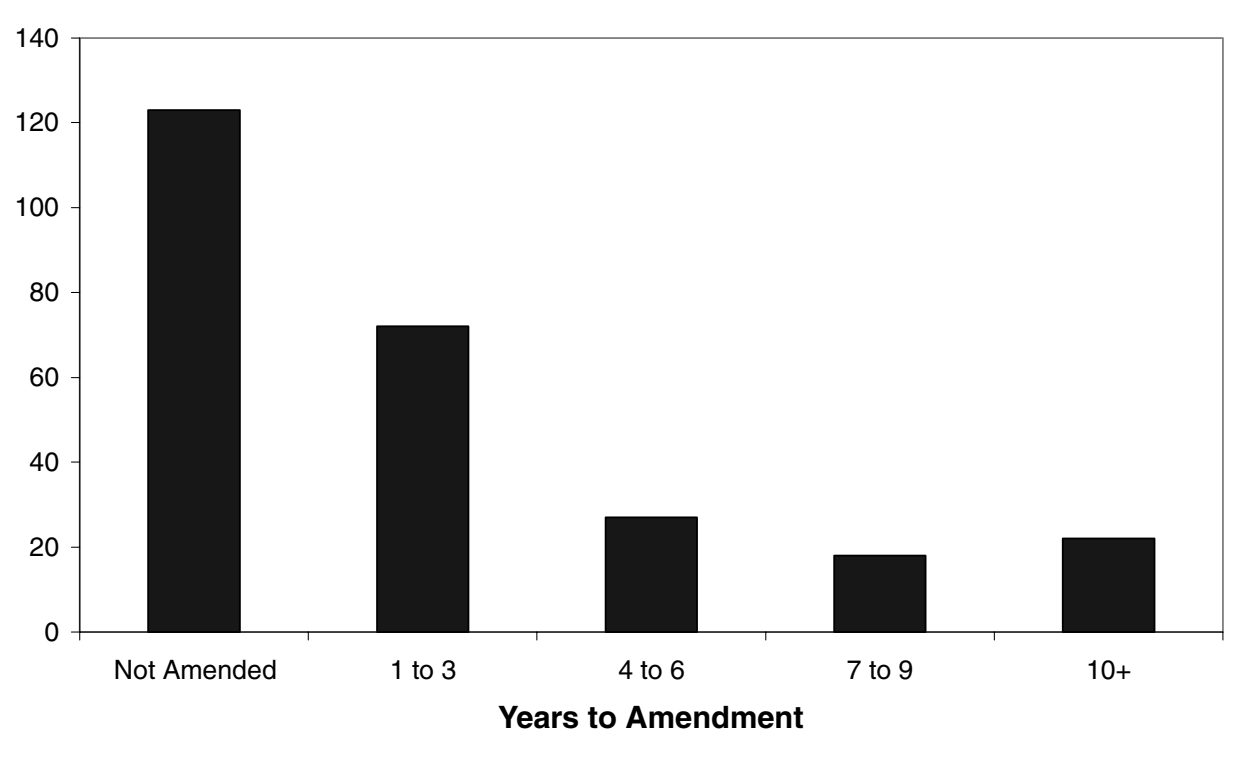

1954 and 2002. ${ }^{10}$ We then use Lexis-Nexis's "statutes at large" module, which lists all future laws that amend any given law, to determine whether and when these major laws have been significantly revised. If the amending law itself was judged by Mayhew to be a major law, we judge it to be a significant amendment. We focus on significant amendments to ensure that we are examining cases where a major law was subject to a serious amendment, rather than a minor or technical amendment or merely a reauthorization of an expiring law. ${ }^{11}$ As shown in Figure 1, of

${ }^{10}$ We begin our analysis with 1954 since the data we use to create two of our independent variables (judicial intervention and public mood) are not available prior to 1953. Nineteen treaties, resolutions, and proposed constitutional amendments that appeared on Mayhew's list were dropped from our analysis since they could not be amended after passage. We also dropped four bills - the Alaska and Hawaii statehood laws, the 1996 omnibus rescission bill, and the 2000 act normalizing relations with China - that could not have been amended after adoption because their primary purpose was completed upon adoption. Finally, we independently went through the list to identify laws that technically could be amended but that both authors believed were unlikely to be amended because they either authorized a public works project (such as the St. Lawrence Seaway Act of 1954) or were designed to address a temporary condition (such as the 1975 New York City and 1979 Chrysler Corporation bailouts; Y2K Planning Act of 2000). In total there were six additional "one-shot" laws (in addition to the four examples listed above) that both authors identified as meeting one of these criteria. Although we have dropped these laws from our analysis, we demonstrate in Table A1 of the online appendix (available on the authors' web sites: http://sitemaker.umich.edu/cshipan/home and http://home.gwu.edu/ forrest) that this decision also has no substantive effect on our results. In short, neither of these screens has a meaningful impact on our findings.

${ }^{11}$ Mayhew's list excludes extensions and reauthorizations that "seemed to me [Mayhew] to offer little new" (Mayhew 2005, 40). the 262 landmark laws included in our analysis, 139-over half-were significantly amended in subsequent years. On average, for those laws that were amended, just over five years elapsed before the original law was subject to a significant amendment.

\section{Dependent Variable and Method}

Our dataset consists of a series of observations for each law, one for each year from the initial enactment until the law is significantly revised. The first observation for each law occurs in the year in which it was enacted, and in this first observation the dependent variable takes a value of 0 . The dependent variable then continues to hold a value of 0 until the year in which it is amended, at which time it takes a value of 1 . Once a law is amended, it is dropped from the dataset in the following year; and if a law has never been amended, the dependent variable remains equal to 0 for the length of the time series. ${ }^{12}$ For example, a law like the Civil Service Reform Act of 1978, which

Although our decision to exclude amendments that did not make the Mayhew list establishes an admittedly high bar, it is a threshold that was established by Mayhew and his sources without consideration of the political conditions that created the underlying law. It also eliminates inconsequential amendments, which occur for virtually every law. Since we are primarily interested in seeing if the conditions that establish a law can induce subsequent revision to the underlying law, this is a reasonable threshold. If we treat every law (including inconsequential laws) that altered any provision of the underlying law as an amendment, our principal findings regarding the importance of enacting coalitions are, not surprisingly, not sustained.

${ }^{12}$ Our statistical approach required us to drop the few laws that were amended during the same year that they were enacted. For 
has never been altered by a major amendment, is coded 0 from 1978, which is the year of enactment, through 2002, when our data is right censored. Superfund, enacted in 1980 , receives a value of 0 from 1980 through 1985, and then receives a value of 1 for 1986, the year in which it was first significantly expanded. After 1986, there are no more observations for the 1980 Superfund law. However, the 1986 toxic waste dump cleanup law that amended the 1980 act is included in our data from 1986 until it is amended in 1990.

Because we are interested in the duration of lawsmore specifically, the amount of time an original agreement lasts before it is subjected to a significant changewe run a Cox regression to estimate our model. In effect, each law has a life, and the failure-when the dependent variable switches from 0 to 1 -occurs when the law is revised by a future law. We utilize a Cox regression to estimate the hazard or "risk" of amendment, rather than an alternative hazard model, since the Cox model does not require us to make strong assumptions about the shape of the underlying hazard (Box-Steffensmeier and Jones 1997). With this method, a positive coefficient indicates an increased risk of amendment (and thus a less durable law) and a negative coefficient indicates a lower risk (and thus a longer-lasting law). ${ }^{13}$

\section{Independent Variables-Enactment Political Characteristics}

First, to test the hypothesis that laws adopted during periods of divided government are more likely to be amended than those adopted during unified control, we create a dummy variable called Divided government at enactment. This variable identifies laws that were enacted during a period when the party that controlled the White House did not also control both the House and the Senate. We expect this variable to have a positive coefficient.

Second, to test whether laws are less durable when the House and Senate hold distinct preferences at the time of enactment, we use Binder's (2003) measure of bicameral differences. This measure, Chamber differences at enactment, records the difference in the proportion of the House and Senate voting aye on passage of a conference report, averaging over the set of conference reports voted on each Congress. Each year of a two-year Congress

example, we excluded the 2001 Air Transportation and Stabilization Act because it was significantly amended by the 2001 Aviation Security Act.

${ }^{13}$ We estimate the model using Stata 8.0's stcox routine. We cluster by law. receives the difference score for that Congress. ${ }^{14}$ Higher scores indicate more disagreement; hence, our hypothesis predicts that the coefficient for this variable will be positive, with greater levels of disagreement increasing the likelihood of future amendments.

\section{Independent Variables-Subsequent Political Characteristics}

Our first two hypotheses about subsequent political conditions examine whether laws are less likely to be amended when partisan control over the current government is divided and when there is greater policy disagreement between the House and Senate. First, to test whether laws are less likely to be amended when control over government is divided, we create a dummy variable, Subsequent divided government, to denote whether the current yearthat is, each year in which a bill could be amendedfeatures divided control. ${ }^{15}$ Whereas Divided government at enactment is constant across all observations associated with each law, Subsequent divided government is updated for each annual observation. Second, to test whether laws are more likely to be amended in periods of House-Senate agreement, we create Subsequent chamber differences, which is a current year version of Chamber differences at enactment. We expect both of these variables to produce negative coefficients, which would indicate that laws are less likely to be amended when partisan control

\footnotetext{
${ }^{14}$ Scholars often use Poole's (1999) Common Space coordinates as a vehicle for placing members of the House and Senate along a single ideological space. These scores are problematic for comparisons across the 1954-2002 period we study (Bailey 2007). Common Space is based upon assumptions that a "legislator serving in both chambers of Congress has the same coordinate throughout his or her [House and Senate] career" and that "the two dimensions are equally salient and lie within a unit circle" (Poole 2004). The validity of these assumptions is questionable over long periods of time (Binder 2003, 143; 2008; Bailey 2007). For this reason, Poole suggests that "these coordinates should be used with caution" (2004). Since Binder's measure avoids these assumptions and looks instead at how the House and Senate vote on the exact same bills, it gives us a strong and comparable way to look directly at interchamber differences over time. Nevertheless, it is important to note that the Binder measure of bicameral differences is an imperfect measure of bicameral differences (Binder 2008; Chiou and Rothenberg 2008). Even though Bailey (2007) introduces an alternative measure that avoids the problems associated with both Common Space and the conference vote measure, it is inappropriate for our purposes since it is designed only to capture preferences on civil rights and civil liberties issues.

${ }^{15}$ For example, if a law was passed in 1974 and then amended in 1979, the Subsequent divided government variable would take on a value of 1 from 1974 through 1976, indicating the presence of divided government in those years, and then 0 from 1977 through 1979 , due to the Democratic party's control of the House, Senate, and presidency in those years.
} 
of government is divided and when the House and Senate have distinct policy preferences.

For each year in our dataset, we also include Stimson's measure of the public mood. Calculated from public opinion polls, Policy mood shows the extent to which the public favors a more liberal, activist role for government. The scores range from 0 to 100 , with higher scores indicating a more liberal mood. ${ }^{16}$ Higher scores in subsequent years should be associated with a higher likelihood of amendment.

We also created a dummy variable, Court attention, to denote whether the Supreme Court made a decision pertaining to each major law during the three years previous to the current year. ${ }^{17}$ Thus, for any law amended in 1969, for example, we utilize Court activity from 1966 through 1968. To determine whether a landmark law was central to a signed opinion of the U.S. Supreme Court, we use the LAW variable in Spaeth (2004), which categorizes the policy content of Court decisions and thus allows us to match Mayhew's major laws to the content of the Court's opinions.

\section{Independent Variables-Law-Specific Characteristics}

As a measure of complexity, we determine the length of each of the Mayhew laws, using as our measure the number of pages for each law as it appears on Lexis-Nexis. To confirm that the number of pages is a consistent measure of the length of laws during the period we examine, we counted the number of words per page for a large number of randomly chosen laws. Six of the laws that we use appear in a different format; for these laws we calculated the number of words per page and adjusted the length so it would be consistent with those of all other laws in our dataset (see Huber and Shipan 2002). Because we expect that complex laws will be more likely to be amended, the coefficient for the Law complexity variable should be positive.

Our next measure taps the divisiveness of the law. To measure Divisiveness, we first calculate the percentage of the House and Senate that voted in favor of the bill on

\footnotetext{
${ }^{16}$ The policy mood dataset is available at http://www.unc.edu/ $\sim$ jstimson/.

${ }^{17}$ For years prior to 1956 , we use the preceding years back to 1953 , which is the first year of data available in Spaeth (2004). We have rerun our analysis based exclusively on observations where we have the proceeding three years of judicial case data (i.e., 1956-2002). These results, nearly identical to what we report below, are available in Table Al of the online appendix.
}

final passage. ${ }^{18}$ We then identify the chamber in which the majority coalition was smaller and treat that chamber's percentage yea as a measure of divisiveness. Because smaller values of this variable indicate a higher level of divisiveness, we expect it to produce a negative coefficient.

Finally, initial tests based on the analysis of Schoenfeld residuals revealed that two of our variables-Chamber differences at enactment and Subsequent chamber differences - have nonproportional effects. To address this issue, and to allow for nonproportionality in the effects of these covariates, we interact each of these variables with the natural $\log$ of time since enactment (i.e., $\ln (t))$ and include these interactive terms as controls in our regressions (e.g., Box-Steffensmeier, Reiter, and Zorn 2003).

\section{Results}

The results of our basic model are shown in Table 1. The overall fit of the Cox regression model is good, as we can reject the null hypothesis that the coefficients are jointly zero beyond the .001 level. More importantly, the results show strong support for our hypotheses, with most of our variables significant at $\mathrm{p}<.05$ or better (one-tailed tests). ${ }^{19}$ Because the coefficients in a hazard model cannot be interpreted as straightforwardly as those in a linear regression, in Table 2 we use the parameter estimates from Model 1 to calculate the percentage change in the hazard rate of amendment for each of the statistically significant variables in Table 1 .

Consistent with our expectations about the relationship between the conditions at the time of enactment and the stability of laws, we find strong support for both hypotheses about enactment conditions, with positive and significant coefficients for both variables. The result for the first of these variables, Divided government at enactment, shows that laws enacted under conditions of divided

\footnotetext{
${ }^{18} \mathrm{We}$ treated the percentage yea on a voice vote as a 100.

${ }^{19}$ We performed several tests that support the robustness of our results. First, our findings are not sensitive to the functional form that we use, with other hazard models, such as Weibull and complementary log-log, yielding similar results. Using logit also produced similar results. Second, we found no evidence of posttreatment bias: our results for the enactment conditions hold up even when we vary the specification by omitting some of the postenactment variables. Third, because so many cases are censored, we calculated predicted values separately for the censored cases. The mean predicted values for the censored cases are higher than the noncensored cases, as would be expected, and both means make substantive sense. Fourth, regression diagnostics confirm the appropriateness of our approach, with visual inspection of the Cox-Snell plot revealing the expected distribution of the residuals when compared to the hazard ratio.
} 
TABLE 1 Significant Amendments of Major Legislation, 1954-2002

\begin{tabular}{|c|c|c|c|}
\hline & Expected Sign & 1 & 2 \\
\hline \multicolumn{4}{|l|}{ Enactment Political Conditions } \\
\hline \multirow[t]{2}{*}{ Divided government at enactment } & + & $0.55^{* * *}$ & $0.52^{* *}$ \\
\hline & & $(0.21)$ & $(0.23)$ \\
\hline \multirow[t]{2}{*}{ Chamber difference at enactment } & + & $34.14^{* * *}$ & $38.20^{* * *}$ \\
\hline & & $(7.29)$ & $(9.71)$ \\
\hline \multicolumn{4}{|l|}{ Subsequent Political Conditions } \\
\hline \multirow[t]{2}{*}{ Subsequent divided government } & - & -0.03 & -0.01 \\
\hline & & $(0.25)$ & $(0.26)$ \\
\hline \multirow[t]{2}{*}{ Subsequent chamber difference } & - & $-35.50^{* * *}$ & $-34.34^{* * *}$ \\
\hline & & $(11.28)$ & $(10.99)$ \\
\hline \multirow[t]{2}{*}{ Policy mood } & + & -0.001 & 0.01 \\
\hline & & $(0.03)$ & $(0.03)$ \\
\hline \multirow[t]{2}{*}{ Court attention } & + & $0.35^{*}$ & $0.42^{* *}$ \\
\hline & & $(0.26)$ & $(0.25)$ \\
\hline \multicolumn{4}{|l|}{ Law-Specific Characteristics } \\
\hline \multirow[t]{2}{*}{ Law complexity } & + & $0.002^{* * *}$ & $0.002^{* * *}$ \\
\hline & & $(0.0003)$ & $(0.0004)$ \\
\hline \multirow[t]{2}{*}{ Divisiveness } & - & $-0.011^{* *}$ & $-0.011^{* *}$ \\
\hline & & $(0.005)$ & $(0.006)$ \\
\hline \multirow[t]{2}{*}{ Sunset provision } & + & - & $0.52^{* * *}$ \\
\hline & & & $(0.21)$ \\
\hline \multicolumn{4}{|l|}{ Nonproportionality controls } \\
\hline \multirow[t]{2}{*}{ Chamber diff. at enactment ${ }^{*} \ln (t)$} & & $-11.71^{* * *}$ & $-13.80^{* * *}$ \\
\hline & & $(4.21)$ & $(5.13)$ \\
\hline \multirow[t]{2}{*}{ Subsequent chamber diff. ${ }^{*} \ln (\mathrm{t})$} & & $9.37^{* *}$ & $12.49^{* * *}$ \\
\hline & & $(4.64)$ & $(5.14)$ \\
\hline Number of observations & & 4169 & 4026 \\
\hline Wald $\chi^{2}$ & & $94.81^{* * *}$ & $86.38^{* * *}$ \\
\hline
\end{tabular}

Note: Cox regression, Breslow method for ties. $*$ denotes $\mathrm{p}<.10,{ }^{* *}$ denotes $\mathrm{p}<.05$, and ${ }^{* * *}$ denotes $\mathrm{p}<.01$, one-tailed tests.

\section{TABle 2 Marginal Effects for Statistically Significant Variables in Model 1}

\begin{tabular}{lcc}
\hline Independent Variable & Change in Variable (from, to) & Percentage Change in the Hazard Rate \\
\hline Divided government at enactment & $0 \rightarrow 1$ & $73.6 \%$ \\
Chamber difference at enactment & $.06 \rightarrow .08$ & $39.2 \%$ \\
Subsequent chamber difference & $.08 \rightarrow .10$ & $-29.2 \%$ \\
Court attention & $0 \rightarrow 1$ & $41.4 \%$ \\
Law complexity & $39.9 \rightarrow 125.6$ & $16.6 \%$ \\
Divisiveness & $66.9 \rightarrow 82.5$ & $-15.8 \%$
\end{tabular}

Note: When calculating the marginal effects, the change represents one standard deviation from the mean for continuous variables and from 0 to 1 for dichotomous variables. We hold all other variables at their mean or, for dichotomous variables, their modal values, and set time at its average value for laws that have been amended.

government are more likely to be amended at any given point in time than those enacted in a period of unified control. More specifically, as shown in Table 2, the hazard rate of a law being amended increases by $73.6 \%$ when the original law was enacted during a period of divided government. Similarly, the Chamber differences at enactment coefficient is positive and significant. Because the effects of this variable are nonproportional, we must take into 
account the coefficient for the interaction of this variable with $\ln (t)$. The combined effect of these terms is positive until almost 19 years after enactment, after which the effect is indistinguishable from zero. ${ }^{20}$ Furthermore, as Table 2 shows, when the chamber difference score increases from its mean to one standard deviation above the mean, the hazard increases by $39.2 \% .^{21}$

Conditions after enactment also play a significant role in affecting the original law's longevity. The combined effect of Subsequent chamber differences and the interaction of this variable with $\ln (t)$ is negative, as predicted, until approximately 25 years after enactment. ${ }^{22}$ This finding lends support to the idea that major laws are less likely to be amended - and thus are more stable - when the two chambers are ideologically distant from each other. In substantive terms, the change in the hazard of amendment when the difference between the chambers moves one standard deviation above the mean is $-29.2 \%$. This

\footnotetext{
${ }^{20}$ That is, the effect of Chamber differences at enactment is strong and positive initially, suggesting that laws enacted in a period of bicameral differences are less durable than laws enacted when the two chambers hold more similar policy views, and the effect of this initial condition then gradually decreases over time.
}

${ }^{21}$ These results are robust to a wide range of other specifications,
as we discuss in subsequent footnotes and in the online appendix.
For example, given that the president is frequently portrayed as
one of the major engines of policy change in the United States, one
might believe that change in partisan control of the White House is
sufficient to induce a policy amendment. In the online appendix's
second table (Table A2, column 1), we test, and reject, this hypothe-
sis. Likewise, in Table A2, we test the proposition that amendments
are disproportionately driven by Republican efforts after 1994 to
undo policies implemented by the Democratic majorities during
the second half of the twentieth century. In Table A3 of the online
appendix, we explore whether the nature of the amending process
varies systematically across different types of policies. Following
Post and Pierson (2005), we included a dummy variable for tax
policies, and following Mayhew (2005), who suggests that Congress
will more frequently need to revisit laws in the areas of foreign pol-
icy and agriculture, we include dummies for policies in those areas.
We also test the proposition that laws passed in the first year of
unified government might be put together especially hastily, which
could increase the likelihood that such bills would be amended in
the future. In each case, the dummy variables employed to test these
conjectures are insignificant, and our other results-including the
enactment year variables-are not affected. We should note that
if we run our analysis employing first-dimension Common Space
scores, instead of the chamber difference measure based upon con-
ference report voting, our finding that bicameral difference at the
time of enactment increases the probability of a subsequent amend-
ment is not sustained. For a discussion of the relative advantages of
the measure we employ, see footnote 14 .

${ }^{22}$ Although there is no intuitive explanation for why the combined effect eventually falls to zero, we note that nearly three-quarters of our observations, and $96 \%$ of laws that are amended, fall into the category of fewer than 25 years (i.e., the point at which the combined effect of the variables is zero). Thus, there are very few observations after this year marker, and almost none of these observations fail. pattern is consistent with the claim that bicameral differences regularly account for the gridlock that can occur.

In contrast, the coefficient for Subsequent divided government is insignificant, indicating that the likelihood of amending a previously adopted law is not greater during periods of unified government. Such a pattern is consistent with observations that the probability of congressional action is consistent across periods of unified and divided government (Mayhew 2005). Likewise, we find no support for the hypothesis that Congress is more likely to amend existing laws when the public is in a more activist mood; indeed, the Policy mood variable takes on a negative sign, rather than a positive sign. Other studies have documented that Congress is more likely to pass important laws during activist periods (e.g., Coleman 1999; but see also Binder 2003). ${ }^{23}$ We suspect our null finding stems from two factors. First, our dependent variable does not capture the direction of the amendments. Some amendments may expand programs, while others may curtail policies previous embraced, and the policy mood variable accounts only for a favorable view toward more government activism. Second, starting in the 1980s, conservatives themselves had ambitious legislative agendas (e.g., the Contract with America in 1995).

We also hypothesized that the relationship between the executive and legislative branches was not the only way that the separation of powers system influences a law's continuity and durability. In particular, we hypothesized that the Supreme Court's involvement in a policy area shapes the likelihood that Congress will amend a previously enacted law. Our Court attention variable is positive, as expected, and significant, although only with a very lenient standard of significance ( $p<.10$, one-tailed). Still, this finding provides us with at least a modicum of support for our hypothesis and is consistent with other studies that have found that Court involvement influences Congress (e.g., Barnes 2004; Eskridge 1991). ${ }^{24}$

Finally, our results show that some characteristics of the laws themselves matter. First, longer bills (Law complexity) are less durable. Indeed, laws that are one standard deviation more complex than average are approximately $17 \%$ more likely to be amended in the future. Given that such bills contain more sections and

\footnotetext{
${ }^{23}$ Dropping this variable from our analysis has no significant impact on our findings (see online appendix, Table A3).

${ }^{24}$ We recognize two weaknesses in our measure that may limit our ability to find support for this hypothesis. First, our measure of judicial involvement is based exclusively on the decisions of the U.S. Supreme Court. Second, when Congress responds to Supreme Court decisions, the incubation period is often longer than the three-year threshold we employed. Our principal findings are robust if one excludes this variable (see online appendix, Table A3).
} 
provisions - in other words, more targets-for potential amendment and are likely to include specific instructions for implementation that future legislators may desire to rewrite, this finding is highly intuitive. Second, the result for Divisive shows that when a law is more highly contested, it is more likely to be amended. ${ }^{25}$

\section{Sunset Provisions}

Model 1 demonstrates that the political conditions at the time a law is enacted influence the probability that a law will be subsequently amended. ${ }^{26}$ In particular, laws enacted during periods of divided government and during periods when common ground between the House and Senate is difficult to find are more likely to be amended than those enacted during periods when partisan and bicameral differences are relatively inconsequential. This outcome suggests that in periods of bicameral and partisan differences, policy opponents can extract concessions that require that a law be revisited or that hinder a law's ability to fulfill the long-term objectives of its primary advocates. One of the most important vehicles for encouraging a law to be revisited are sunset provisions. Although these provisions can be used for a variety of reasons (such as uncertainty about a policy's effectiveness), these provisions are frequently employed as a mechanism for building coalitions.

Although there are a number of provisions that can induce a legislative amendment, one type of provision in particular-sunset provisions-mandates that a law either be amended or allowed to die. Inevitably, this leads one to ask whether our findings in Model 1 are driven exclusively by these provisions. To control for this possibility, in Model 2 we add a dummy variable to denote those laws that have a key provision that expires in the current

\footnotetext{
${ }^{25} \mathrm{We}$ also tested whether variables that indicate the presence of overwhelming support for a law influenced the likelihood that it would be amended. We found that bills that became law over a presidential veto or that were passed on a voice vote were less likely to be amended than other bills. Including these variables did not affect our findings (see Table A3 of the online appendix).

${ }^{26}$ Because we are interested in changes to the letter of the law, rather than programmatic changes, our dependent variable is limited to statutory amendments. Nevertheless, there are other vehicles that can be used to induce programmatic changes and thus ameliorate the need to amend a law. One of the most prominent tools available to Congress is the appropriations process. Because our dependent variable fails to capture programmatic changes that result from the appropriations process, one might wonder whether our results are driven exclusively by laws that are not dependent upon federal appropriations for their implementation. We explore (and reject) this possibility in the online appendix (Table A5).
}

session of Congress because of a sunset provision. ${ }^{27}$ This variable is set equal to 0 initially and then changed to 1 in the Congress in which the sunset occurs. As expected, the coefficient for this variable is statistically significant, indicating that laws enacted with a sunset provision are more likely to be amended. More importantly, the main lesson one draws from Model 2 is that our principal finding still holds: enactment conditions broadly and significantly account for the probability that a law will be subsequently amended. Similarly, we find continued support for the effects of features specific to the law and for subsequent political conditions, and also find stronger support for the effect of Court attention.

\section{Conclusion}

As many scholars have observed, elected officials, organized interests, and citizens pursue their policy agendas with an eye on the uncertainty that pervades any nation's politics. Indeed, such actors live in a world where their only certainty is that the politics of tomorrow might not much resemble the politics of today. In such an environment, successful coalitions undoubtedly seek to build on their policy victories by locking in their gains for the

${ }^{27}$ This variable was created using a multistep process. We began with the list of laws that were on the Mayhew list and that Epstein and O'Halloran (1999) identified as having a sunset provision. This list of laws is based upon a reading of the Congressional Quarterly Almanac legislative summaries for each of the Mayhew laws (1999, 275). Because Epstein and O'Halloran $(1999,277)$ identified these laws until 1992, we have limited our analysis in Model 2 to the 1954-92 period. This time period, however, is long enough for us to reach generalizable conclusions. Based upon our reading of the Congressional Quarterly summaries for each law, we identified the year the sunset provisions took effect. A sunset dummy was then turned on for each observation associated with each law beginning in the Congress where the provision took effect. Because there is some uncertainty about exactly when this dummy variable should change from 0 to 1 , we also reestimated this equation using alternate versions of this variable. In Table A4 of the online appendix we report the results that we obtain if the dummy variable changes to 1 in the year of the sunset; the year after the sunset; and the year prior to the sunset. All are significant and all demonstrate that the findings for our other variables are robust.

In instances where the law had more than one sunset provision, we used the earlier sunset, unless it was clearly related to a minor provision. For example, the Demonstration Cities and Metropolitan Development Act of 1966 had a 1969 sunset for the demonstration project for cities and a 1972 sunset for a mortgage insurance program. We used the 1969 sunset provision since it came first. In contrast, the Airport Airway and Development Act of 1970 set minimum spending levels on improvements and established a funding mechanism that expired in 1980. The act also had a small grant program that expired in 1973. Because we saw the 1980 sunset provision as being central to the bill, we treated this bill as having a 10 -year sunset provision. Using alternate codings in such cases had no effect on our results. 
future. The construction of public laws, in other words, is a dynamic process that unfolds over time.

Where others have assessed the importance of institutional constraints and policy feedback loops in explaining the stability of public laws, we offer a perspective that also looks to the political conditions that underlie the original construction of public laws. Our analysis suggests that this durability is shaped not only by characteristics of the law, but also by initial and subsequent political conditions and by interactions across the branches of government. Ideological and partisan alignments across branches and within Congress indelibly shape the prospects for stable laws by molding both the initial configuration of the law and its subsequent chances of revision. By moving away from the more customary "snapshot" views of the legislative process, our focus on changes to the law allows us to explore the evolutionary character of lawmaking, an aspect of laws that is often left unexplored by legislative scholars.

This more dynamic view of lawmaking sheds new light on the influence of political parties on lawmaking. David Mayhew and others have concluded that divided government makes little difference in explaining the passage of landmark laws. According to this view, we govern similarly, whether divided or unified control prevails. Although this view has engendered debate, we, like Mayhew, find no support for the notion that during periods of divided government Congress is less likely to act-at least in terms of amending major laws. Divided government is not a shield that protects previously adopted laws from subsequent amendment.

Although debate about the effect of divided government on the passage of laws continues, we show a previously unnoticed effect of divided government. When unified government prevails, the majority party is able to use its governing powers to craft legislative agreements that are more likely to endure. Party alignments thus make a difference for policy choices, a finding underscored decades ago by Schattschneider (1942) and Key (1964). Still, more than party politics matter: bicameral differences shape not only the likelihood of enacting new law, but also the chances that such laws will endure.

Since the publication of Divided We Govern, many other studies have fine-tuned Mayhew's analysis in an attempt to discern whether divided government decreases the odds that major laws will be passed (Fiorina 1996; Kelly 1993; Sinclair 2006). Our analysis takes a different approach by looking at an alternative, and previously unnoticed, effect of divided government-namely, how divided government affects the durability of a law, defined here as the length of time a law exists in its original form before it is amended. This approach, then, is complementary to Mayhew's. Moreover, it is directly in line with a question that Mayhew explores briefly in the conclusion of Divided We Govern, in which he asks, "Even if important laws win enactment just as often under conditions of divided party control, might they not be worse laws? Isn't 'seriously defective legislation' a likelier result?" $(2005,180)$. Although the value one attaches to a law, and thus its quality, varies along with one's policy preferences, our findings make clear that future governing coalitions are more likely to amend laws that were adopted during periods of divided control. To the extent that these amendments are driven by defects in the underlying law, our findings suggest that legislation enacted during periods of conflict have provisions that are either flawed or incapable of responding to exogenous shocks.

More generally, the adoption of large- $\mathrm{N}$ quantitative analysis to explore the determinants of durability offers a chance to draw generalizable conclusions about legal stability and change. Our approach has its limits as well. First, although we know when landmark laws have been amended, we treat all types of changes alike, regardless of whether the amendment expands, contracts, or fundamentally alters existing public law. Although identifying whether an amendment strengthens or weakens an underlying law requires the sort of subjective analysis that is difficult given that laws frequently have multiple goals and ambiguous policy consequences, it is an important step in understanding why laws enacted by weak coalitions are more likely to be amended in the future. Without knowing whether an amendment weakens or strengthens the underlying law, we do not know whether the amendments were provoked because of the initial law's failure or because its popularity led proponents to extend the law.

Second, we limit our analysis to amendments contained in laws that were identified by Mayhew as being significant. We have no doubt that on occasion such a constraint may obscure important changes in the law. Indeed, many of the most important developments in the evolution of the law occur through bureaucratic and judicial interpretation, not formal legislative action. Finally, although we draw on Stimson's policy mood measure to determine whether the public favors a more or less activist role for government in general, we have no good indicators of when Congress's attention is focused on a particular law and its need for revision. Previous studies have demonstrated that sharp changes in attention can induce radical policy and budgetary shifts (Jones and Baumgartner 2005a, 2005b; Jones, Sulkin, and Larsen 2003). These shortcomings create plenty of room for improving large- $\mathrm{N}$ analyses of durability. 
Still, our most striking finding gives us confidence that our approach taps an important and unrecognized relationship between enacting conditions and durability. Major laws enacted in periods of divided government are significantly more likely to be amended subsequently, compared to major laws adopted in periods of unified control. This finding increases our confidence that the political compromises required to pass legislation under divided control undermine policy proponents' abilities to entrench their view of the new public law, to sink their policy goals into legislative concrete. The influence of subsequent electoral and policy alignments on the likelihood of revisiting public law also suggests that political conditions have a lasting imprint on the character of policy compromises.

In the Economic Analysis of Law, Posner argues that "once a statute is passed, it is unlikely, given the press of other legislative business, to soon be substantially altered or repealed. The impediments to legislation endow legislation, once enacted, with a measure of durability, thereby increasing the value of and hence the demand for legislation" $(1992,531)$. Our analysis suggests that Posner's assessment underestimates important differences in the political context in which legislative bargains are formed and sealed. Not all laws are created alike, and rarely are they left unchanged.

\section{References}

Abraham, Spencer. 2000. "Testimony on Campaign Finance Reform." United States Senate, Committee on Rules and Administration. May 17.

Adler, Scott E., Michael Berry, Cherie Maestas, and John Wilkerson. 2005. "The Politics of Legislative Specialization: Issues and Considerations in Measurement, 96th-105th Congresses." Presented at the 2005 meeting of the Midwest Political Science Association.

Adler, Scott E., and John S. Lapinski. 2006. The Macropolitics of Congress. Princeton, NJ: Princeton University Press.

Arnold, Douglas R. 1990. The Logic of Congressional Action. New Haven, CT: Yale University Press.

Bailey, Michael A. 2007. "Comparable Preference Estimates across Time and Institutions for the Court, Congress, and Presidency." American Journal of Political Science 51(3): 43348.

Barnes, Jeb. 2004. Overruled? Legislative Overrides, Pluralism, and Contemporary Court-Congress Relations. Stanford, CA: Stanford University Press.

Baumgartner, Frank R., and Bryan D. Jones. 1993. Agendas and Instability in American Politics. Chicago: University of Chicago Press.

Baumgartner, Frank R., and Bryan D. Jones. 2005. The Politics of Attention. Chicago: University of Chicago Press.
Berry, Christopher R., Barry C. Burden, and William G. Howell. 2006. "Matters of Life and Death: The Durability of Discretionary Programs 1970-2004." Presented at the 2006 meeting of the American Political Science Association.

Binder, Sarah A. 2003. Stalemate: Causes and Consequences of Legislative Gridlock. Washington, DC: Brookings.

Binder, Sarah A. 2008. "Taking the Measure of Congress: Reply to Chiou and Rothenberg." Political Analysis 16: Forthcoming.

Binder, Sarah A., and Steven S. Smith. 1996. Politics or Principle? Washington, DC: Brookings.

Box-Steffensmeier, Janet M., and Bradford S. Jones. 1997. "Time Is of the Essence: Event History Models in Political Science.” American Journal of Political Science 41(4): 1414-61.

Box-Steffensmeier, Janet M., Dan Reiter, and Christopher Zorn. 2003. "Nonproportional Hazards and Event History Analysis in International Relations." Journal of Conflict Resolution 47(1): 33-53.

Brady, David, and Craig Volden. 1998. Revolving Gridlock. Boulder, CO: Westview.

Chiou, Fang-Yi, and Lawrence S. Rothenberg. 2008. "Comparing Legislators and Legislatures: The Dynamics of Legislative Gridlock Reconsidered.” Political Analysis 16. Forthcoming.

Coleman, John J. 1999. “Unified Government, Divided Government, and Party Responsiveness." American Political Science Review 93(December): 821-36.

Covington, Cary R., and Andrew A. Bargen. 2004. "Comparing Floor-Dominated and Party-Dominated Explanations of Policy Change in the House of Representatives." Journal of Politics 66(November): 1069-88.

de Figueiredo, Rui J. P. 2002. "Electoral Competition, Political Uncertainty, and Policy Insulation." American Political Science Review 96(June): 321-33.

Derthick, Martha, and Paul J. Quirk. 1985. The Politics of Deregulation. Washington, DC: Brookings.

Epstein, David, and Sharyn O'Halloran. 1999. Delegating Powers. New York: Cambridge University Press.

Eskridge, William N., Jr. 1991. "Overriding Supreme Court Statutory Interpretation Decisions." Georgetown Law Review 101(2): 331-455.

Ferejohn, John, and Charles Shipan. 1990. "Congressional Influence on Bureaucracy." Journal of Law, Economics and Organization 6: 1-21.

Fiorina, Morris. 1996. Divided Government. 2nd ed. Boston: Allyn Bacon.

Hacker, Jacob S. 2002. The Divided Welfare State. New York: Cambridge University Press.

Hacker, Jacob S. 2005. "Policy Drift: The Hidden Politics of U.S. Welfare State Retrenchment." In Beyond Continuity: Institutional Change in Advanced Political Economies, ed. Wolfgang Streeck and Kathleen Thelen. New York: Oxford University Press, 40-82.

Hacker, Jacob, and Paul Pierson. 2002. "Business Power and Social Policy: Employers and the Formation of the American Welfare State." Politics and Society 30(2): 277-35.

Hammond, Thomas H., and Gary J. Miller. 1987. "The Core of the Constitution." American Political Science Review 81(4): $1155-77$. 
Harris, John F., and John E. Yang. 2001. "Clinton to Sign Bill Overhauling Welfare.” Washington Post, August 1.

Hausegger, Lori, and Lawrence Baum. 1999. "Inviting Congressional Action: A Study of Supreme Court Motivations in Statutory Interpretation." American Journal of Political Science 43(1): 162-85.

Howell, William, Scott Adler, Charles Cameron, and Charles Riemann. 2000. "Divided Government and the Legislative Productivity of Congress, 1945-94." Legislative Studies Quarterly 25(May): 285-312.

Huber, John D., and Charles R. Shipan 2002. Deliberate Discretion? New York: Cambridge University Press.

Huber, John D., Charles R. Shipan, and Madelaine Pfahler. 2001. "Legislatures and Statutory Control of Bureaucracy." American Journal of Political Science 45(2): 330-45.

Jones, Bryan D., and Frank R. Baumgartner. 2005a. "A Model of Choice for Public Policy." Journal of Public Administration Research and Theory 15(3): 325-51.

Jones, Bryan D., and Frank R. Baumgartner. 2005b. The Politics of Attention. Chicago: University of Chicago Press.

Jones, Bryan D., Tracy Sulkin, and Heather Larsen. 2003. "Policy Punctuations in American Political Institutions." American Political Science Review 97(1): 151-70.

Katznelson, Ira, and John S. Lapinski. 2006. "The Substance of Representation: Studying Policy Content and Legislative Behavior." In The Macropolitics of Congress, ed. Scott E. Adler and John S. Lapinski. Princeton, NJ: Princeton University Press, 96-126.

Katznelson, Ira, John S. Lapinski, and Rose Razaghian. 2001. "Policy Space and Voting Coalitions in Congress: The Bearing of Policy on Politics, 1930-1954." Institute for Social and Economic Research and Policy, Working Paper 0102.

Kelly, Sean Q. 1993. "Divided We Govern? A Reassessment.” Polity 25(Spring): 475-84.

Key, V. O., Jr. 1964. Politics, Parties, and Pressure Groups. 5th ed. New York: Thomas Crowell.

Kingdon, John. 1984. Agendas, Alternatives, and Public Policies. Boston: Little, Brown.

Krehbiel, Keith. 1998. Pivotal Politics. Chicago: University of Chicago Press.

Landes, William, and Richard A. Posner. 1975. "The Independent Judiciary in an Interest-Group Perspective." Journal of Law and Economics 18(3): 875-911.

Lewis, David E. 2003. Presidents and the Politics of Agency Design. Stanford, CA: Stanford University Press.

Lewis, David E. 2004. "The Adverse Consequences of the Politics of Agency Design for Presidential Management in the United States: The Relative Durability of Insulated Agencies." British Journal of Political Science 34(3): 377-404.

Lovell, George I. 2003. Legislative Deferrals. Cambridge: Cambridge University Press.

Lowi, Theodore J. 1964. "American Business, Public Policy, Case Studies, and Political Theory.” World Politics 16(4): 677-715.

Mayhew, David R. 1993. "Reply: Let's Stick with the Longer List." Polity 25(3): 485-88.
Mayhew, David R. 2005. Divided We Govern: Party Control, Lawmaking, and Investigations 1946-2002. 2nd ed. New Haven, CT: Yale University Press.

McCubbins, Mathew D., Roger G. Noll, and Barry R. Weingast. 1989. "Structure and Process, Politics and Policy: Administrative Arrangements and the Political Control of Agencies." Virginia Law Review 75(2): 431-82.

Moe, Terry M. 1989. “The Politics of Bureaucratic Structure.” In Can the Government Govern? ed. John E. Chubb and Paul E. Peterson. Washington, DC: Brookings, 267-329.

Niskanen, William A. 2003. "A Case for Divided Government.” Cato Policy Report March/April 2003: 2.

Patashnik, Eric M. 2000. Putting Trust in the U.S. Budget: Federal Trust Funds and the Politics of Commitment. New York: Cambridge University Press.

Patashnik, Eric M. 2003. "After the Public Interest Prevails: The Political Sustainability of Policy Reform." Governance 16(April): 203-34.

Patashnik, Eric M. 2008. Reforms at Risk: What Happens after Major Policy Changes Are Enacted. Princeton, NJ: Princeton University Press.

Pierson, Paul. 1994. Dismantling the Welfare State? Reagan, Thatcher and the Politics of Retrenchment. New York: Cambridge University Press.

Pierson, Paul. 2003. "Public Policies as Institutions." Presented at the Yale Conference on Crafting and Operating Institutions.

Pierson, Paul. 2004. “Ahead of Its Time: On Martha Derthick's Policymaking for Social Security.” PS: Political Science and Politics (July): 441-42.

Poole, Keith T. 1998. "Recovering a Basic Space from a Set of Issue Scales.” American Journal of Political Science 42(3): 954-93.

Poole, Keith T. 2004. "Description of Nominate Data, July 13, 2004." http://voteview.com/page2a.htm (accessed November 9, 2007).

Posner, Richard A. 1992. Economic Analysis of Law. 4th ed. Boston: Little, Brown.

Post, Alison E., and Paul Pierson. 2005. "How a Law Stays a Law: The Durability of U.S. Tax Breaks 1967-2003.” Presented at the annual meeting of the American Political Science Association, Washington.

Saletan, William. 2001. “The Money Jungle.” Slate. March 22. (http://slate.msn.com/id/102994).

Schattschneider, E. E. 1942. Party Government. New York: Holt, Rinehart, and Winston.

Shipan, Charles R. 1997. Designing Judicial Review. Ann Arbor: University of Michigan Press.

Shipan, Charles R. 2000. "The Legislative Design of Judicial Review: A Formal Analysis." Journal of Theoretical Politics 12(3): 269-304.

Sinclair, Barbara. 2006. Party Wars. Norman: University of Oklahoma Press.

Smith, Joseph L. 2005. “Congress Opens the Courthouse Doors: Statutory Changes to Judicial Review under the Clean Air Act.” Political Research Quarterly 58(March): 139-49. 
Smith, Joseph L. 2006. "Judicial Procedures as Instruments of Political Control: Congress' Strategic Use of Citizen Suits.” Legislative Studies Quarterly 31(2): 283-305.

Spaeth, Harold J. 2004. "The Original Supreme Court Database." Available via the Ulmer Project (http://www.as .uky.edu/polisci/ulmerproject/).

Stimson, James A. 1991. Public Opinion in America. Boulder, CO: Westview Press.

Sundquist, James. 1988. "Needed: A Political Theory for the New Era of Coalition Government in the United
States." Political Science Quarterly 103(Winter): 61315.

Tsebelis, George. 2002. Veto Players. Princeton, NJ: Princeton University Press.

Tsebelis, George, and Jeanette Money. 1997. Bicameralism. New York: Cambridge University Press.

Vietor, Richard H. K. 1984. Energy Policy in America since 1945. New York: Cambridge University Press.

Weaver, Kent R. 1988. Automatic Government. Washington, DC: Brookings Institution. 